\title{
Effectiveness of Gender Education in Ukraine as the Implementation of the Principle of Gender Parity
}

\author{
Olga Shcholokova \\ Dragomanov National Pedagogical University, Ukraine \\ https://orcid.org/0000-0001-9496-828X \\ Olena Karpenko \\ Dragomanov National Pedagogical University, Ukraine \\ https://orcid.org/0000-0002-6715-2899 \\ Zhanna Petrochko \\ Borys Grinchenko Kyiv University, Ukraine \\ https://orcid.org/0000-0002-4413-1243 \\ Vira Kuzmenko \\ Dragomanov National Pedagogical University, Ukraine \\ https://orcid.org/0000-0003-4709-6081 \\ Tetyana Holubenko \\ Dragomanov National Pedagogical University, Ukraine \\ https://orcid.org/0000-0002-3042-888X
}

\begin{abstract}
The purpose of the study was to investigate gender stereotypes and prejudices that negatively affect women and men. It is important that students be aware of gender issues and are able to critically reflect on their own prejudices and gender "matrices" of the education system in the context of 'gender $\mathrm{v}$ sex'. A questionnaire was the main method of data collection. A sociological survey, "Students on the problems of gender equality" was conducted at V.N. Karazin Kharkiv National University (Ukraine). The survey was conducted based on a three-level probability sample, which ensures the representativeness of the data. The effectiveness of aspects of gender education in secondary schools and higher education institutions has been assessed. At school, the problems of gender equality are not discussed enough; more than $80 \%$ of all respondents did not learn anything at school on this topic. Every third student discussed the issues of gender parity in the university classes. As a rule, this was done in general courses (sociology, philosophy, law), as there are no special
\end{abstract}


disciplines on gender parity in society. The study reached the conclusion that respondents were unfamiliar with gender issues, so they might sometimes not see (perceive) certain gender prejudices and oppression in a student body, which encourages more attention to the development of gender-oriented disciplines of Ukrainian universities.

Keywords: gender pedagogy; gender parity; sociological study; values; gender stereotypes

\section{Introduction}

In the modern world there are contradictions between the declared gender parity and the real asymmetry of social and family roles inherent in both genders, as well as between the universalization of gender functions, recognition of the importance of women's social activities and the stability of traditional gender stereotypes. In this situation, the importance of gender education as a necessary component of successful social adaptation of youth is growing (Bailey \& Graves, 2016). In the context of the expansion of the European integration space, it is an important factor in the formation of tolerant behaviour of boys and girls and ensuring their full self-realization as individuals in various spheres of public life (Struffolino et al., 2016).

The study of gender aspects in youth education at all levels of education (from secondary to higher education) provides an opportunity to clarify the hierarchy of its subjective values, predict future life practices, and to better understand the age and cultural specifics of young people's understanding of gender priorities. That is why in the European educational space effective crosscultural studies of problems of gender socialization and gender education are carried out (Tetzner \& Schuth, 2016).

The defining indicators of today are political, economic, social instability, growth and contradictions in the flow of information through innovative technologies, globalization and expansion of the cross-cultural sphere of interactions among people, and the transformation of management and educational spaces. According to such transformations, the requirements of the social, professional and personal development of a young person are increasing (Setti, 2017). This has contributed to the active attention of scientists to the development of scientific theses for the development of the personal sphere of youth, including gender tolerance in young men and women, in order to improve their gender culture, develop skills to resist stereotyping and reduce propensity for interpersonal conflicts (Karhina et al., 2016).

Therefore, we are most often confronted with certain gender stereotypes, that is, biased ideas, according to which women and men are arbitrarily determined by the characteristics and roles established and limited by their gender. At the same time, gender stereotypes can limit the development of natural talents and abilities of girls and boys, women and men, as well as their educational and professional experience and life potential in general (Muralidharan \& Sheth, 2016). That is why research and analysis of gender issues and stereotypes of the 
professional environment are urgent, relevant and require a new understanding.

In addition, in order to identify additional principles and trends in the development and implementation of the state's gender policy in Ukraine, there still is an urgent need for open data for empirical analysis of gender issues in the professional environment of public institutions (Dvoriak et al., 2020). The professional environment within the Ukraine may benefit from a thorough analysis of available and ongoing data.

Breaking the traditional system of gender stratification, sudden weakening of the polarization of female and male social roles, changing cultural stereotypes of masculinity and femininity, and profound transformations in marital and family relations have necessitated a new gender approach in the organization of the educational process. In addition, the problem of gender education becomes especially relevant in conditions of modernization of secondary schools, which main task is the formation of students' civic responsibility, initiative, independence, tolerance, and ability to successfully socialize in society (Gibson et al., 2016). However, different methodological approaches, contradictions in the interpretation of certain concepts, and lack of systematic treatment of gender issues in domestic pedagogy create difficulties and delays, especially noticeable in the field of practical implementation of the principles of gender education in Ukrainian educational institutions. In this situation, the relevance of comprehensive coverage of relevant experience, generalized in foreign, especially European, pedagogical science, is growing.

The purpose of the study was to investigate gender stereotypes and prejudices that negatively affect women and men; it is important that students are aware of gender issues and are able to critically reflect on their own prejudices and gender "matrices" of the education system. Quality education is the key to women's and men's economic independence.

\section{Literature review}

Representatives of various branches of psychological science attach special importance to the above-mentioned issues. Within the general, social and gender psychology, attention is paid to the problem of socialization among the modern young generation, in particular, aspects of tolerance development as a factor in the formation of mature relationships of different genders (Caner et al., 2016; Reimão \& Taş, 2017), adequate acceptance of their social role (Bertocchi \& Bozzano, 2016), acquisition of ethical principles and value systems of intergender relations (Baker \& Whitehead, 2016; Warin \& Adriany, 2017; Amado \& Diniz, 2017), building of family life and marital relations (Dobson \& Ringrose, 2016; Cama et al., 2016). At the same time, the issue of gender parity as one of the conditions for readiness for tolerant interaction in intergender relations (Magnuson et al., 2016; Salavera et al., 2017), and political (Francis \& Chiyem, 2017; Molina, 2016), and social life is becoming increasingly important in developmental psychology (Assari, 2017; Baizan et al., 2016. 
Psychologists studying intergender interactions, conducted a sub-contracted investigation of gender tolerance as a social norm and value in intergender interactions (Klein, 2016), as a characteristic of the value attitude of the individual to members of different genders (Kim \& Park, 2017), and as a process and means of harmonizing intergender relations in society (Kleven \& Landais, 2017). Researchers also explored the structural components, types and levels of gender tolerance (Núñez-Peña et al., 2016; Orakci et al., 2016), and touched on elements of its development (Burke, 2017; Van der Vleuten et al., 2016).

Modern psychologists point out that the development of gender tolerance in adolescence is associated with the growth of personal potential, emotional maturity, openness, enrichment of life experience (Leyva, 2017), and maturation of cognitive and emotional-volitional processes (Pampel et al., 2017), resulting in the development of cultural, social and gender identity $(X u, 2016)$, social, interethnic and personal tolerance (Subbaye \& Vithal, 2017), the actualization of their own life position as a result of increased interest in themselves, the development of communicative and personal reflection, and the desire to defend their own position (Colgan, 2017).

As scientists have found, the processes of socialization and mastery of leading activities determine the development of value orientations of a personality in adolescence, with which they do not always agree, and which might serve as a basis for behaviour in representatives of different genders, which causes interpersonal conflict (Kellett \& Fitton, 2017). Studying the main causes of conflict in youth's environments, researchers point out that in the presence of a psychological culture (Eddy \& Brownell, 2016), the youths can overcome communication barriers (Hauw et al., 2017), and resolve complex conflict situations, including gender issues, and show tolerance. On the other hand, differences in perception and withholding information from young people (Tansel \& Güngör, 2016), unconstructive behaviour of conflicting parties (Cotton et al., 2016), and an imbalance in their social roles and corresponding gender-role behaviour (Addabbo et al., 2016) lead to a decrease in gender tolerance. Thus, the results of these studies show that the ability to resolve conflict situations increases the potential for gender tolerance.

\section{Methodology}

From 30 April to 20 July 2021 the sociological study "Students on the problems of gender equality" was conducted at the V.N. Karazin Kharkiv National University (Ukraine). The field stage of the study (survey) took place from 11 May to 29 June 2021. 800 male and female students $(n=800)$ who are citizens of Ukraine and studied full-time in departments of higher education institutions in the city of Kharkiv were interviewed.

Sample. The survey was conducted based on three-level probability sampling, which ensured the representativeness of the data for students of Kharkiv (fulltime departments, citizens of Ukraine). Initially, a randomized selection of faculties was conducted. At this stage the selection was stratified by types of faculties (socio-humanities, natural and technical). At the next stage, a random 
selection of student groups was conducted. The third stage was the random selection of respondents in groups.

The size of the sample is indicated taking into account the data set based on the results of data consistency control and correction of filling and input errors. Questionnaires that contained fundamental violations of the rules of the survey were removed from the set and not included in the analysis.

Statistical errors with a probability of $95 \%$ do not exceed (data on statistical errors are given without taking into account the design effect of the sample): $3.5 \%$ for values close to $50 \% ; 3.0 \%$ for values close to $25 \%$ or $75 \%$; $2.1 \%$ for values close to $10 \%$ or $90 \% ; 1.5 \%$ for values close to $5 \%$ or $95 \% ; 0.7 \%$ for values close to $1 \%$ or $99 \%$.

The sample consisted of 39\% males and $61 \%$ females, aged between 16 and 32 (with a mean age of 19.6, standard deviation of 1.8). Fifty-four percent of the respondents did their studies in sociology and the humanities (including law and/or economics), and $46 \%$ studied at natural sciences or technical faculties. The participants in the survey were fairly evenly distributed over the courses: $21 \%$ studied in the first course, $27 \%$ in the second course, $25 \%$ in the third course, and $27 \%$ in the fourth and fifth courses.

Before entering the HEI (graduating from secondary school), 68\% of the respondents had lived in the Kharkiv region, while 32\% came from other regions of the Ukraine. The places of residence of the respondents were distributed as depicted in Table 1.

Table 1: Distribution of places of residence of respondents by localities

\begin{tabular}{|l|l|}
\hline Kharkiv region - 68\% & $38 \%$ \\
\hline The city of Kharkiv & $15 \%$ \\
\hline District centre & $8 \%$ \\
\hline Other city or urban settlement (SMT) & $6 \%$ \\
\hline Village & $6 \%$ \\
\hline Other regions of Ukraine - 32\% & $14 \%$ \\
\hline Regional centre & $10 \%$ \\
\hline District centre & $3 \%$ \\
\hline Other city or SMT &
\end{tabular}

The parameters of the sample, in general, reflect the model of the general population and meet the requirements of representativeness, which allows for extending the findings of the study to all students and citizens of the Ukraine, who study full-time at departments of HEIs in Kharkiv. The characteristics of the respondents are given in Appendix A.

Input and further processing of primary information obtained from the questionnaires was done using software packages for processing sociological questionnaires, SPSS 11. 


\section{Results}

Political changes, the strengthening of European integration orientations, and the signing of the Association Agreement with the European Union (EU) by Ukraine have created an important new impetus for the integration of the gender approach in education after 2014. Among the most important changes of this period, that is, those that have a significant potential for systemic changes in Ukrainian education, we note the main ones.

(i) Institutional consolidation of anti-discrimination examination of school textbooks and the creation of a working group on gender equality policy and anti-discrimination in education by the Ministry of Education and Science of Ukraine (MES of Ukraine).

(ii) Close cooperation of experts and researchers with the education community and the reaching of expert knowledge beyond the academic community and the university audience.

(iii) A growing public interest in gender content knowledge, the emergence of critical reflection on the practices of gender education in kindergartens and schools, and the grassroots mobilization of students to combat sexism in universities.

An important indicator of the effectiveness of gender education is lessons in secondary school in which teachers discuss the issue of gender equality with the learners. In general, only $18 \%$ of male and female students mentioned that gender issues were discussed in the secondary school. Others either said, "No, they didn't talk about it at school" confidently, or said "no" less confidently because they did not remember such discussions (Figure 1).

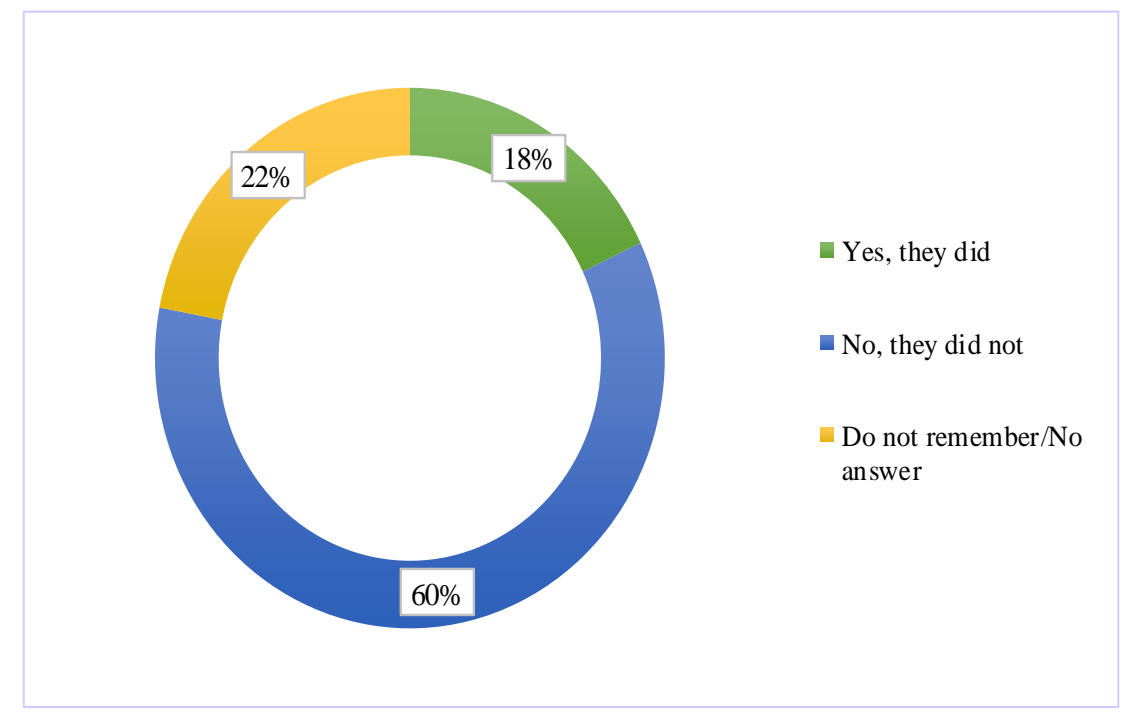

Figure 1: "Please, indicate whether your school teachers told you about gender equality" \%. Population: all respondents

$$
(\mathrm{n}=800)
$$

There were no significant statistical differences in the answers of males and females, in the answers of students from socio-humanities faculties and students from natural sciences and technical faculties, as well as in the answers 
of respondents living in localities of different types. The only significant difference was found in the responses of first-year students, among whom significantly more indicated they had learned about the problem of gender equality in the secondary school $(27 \%)$, while the responses of second-, third-, fourth- and fifth-year students were identical (Figure 2).

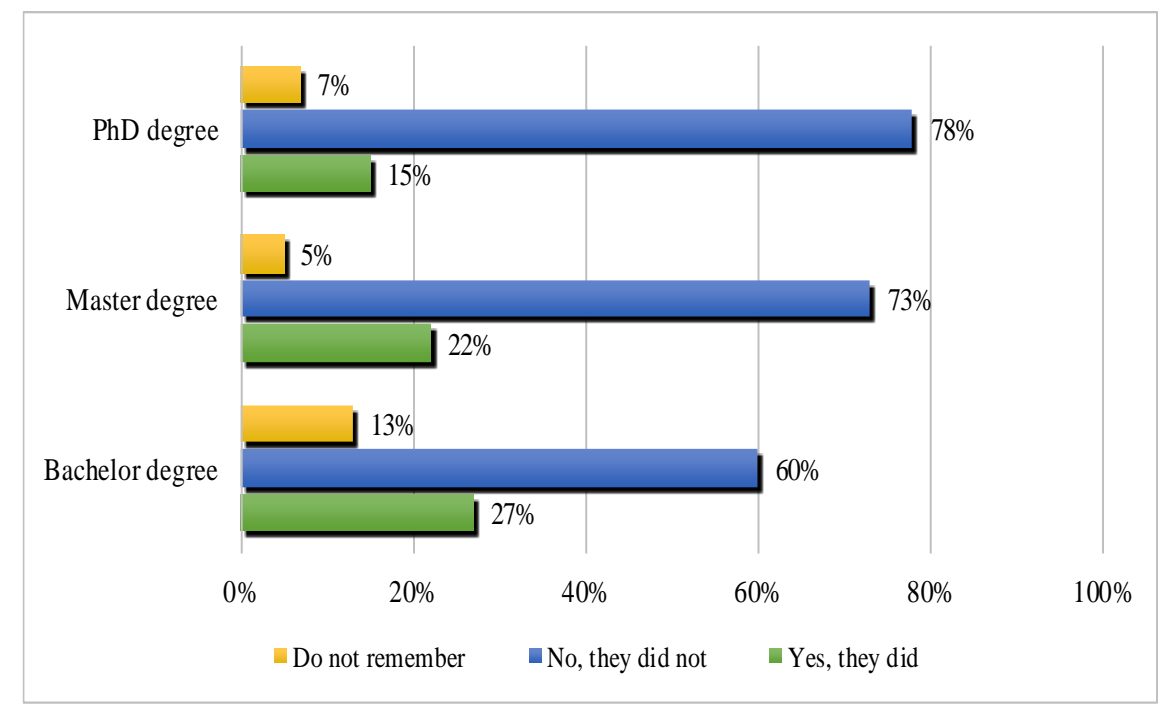

Figure 2: "Please, indicate whether your school teachers told you about gender equality." Distribution of answers depending on the level of education of respondents, \%. Populations: students with degrees of: «Bachelor's» $(n=384)$, «Master's»

$$
(\mathrm{n}=202), \ll \mathrm{PhD} »(\mathrm{n}=214)
$$

This difference is due to students with the degree of "bachelor" still had gender equality lessons in some schools. It is also possible that the retrospective nature of the question had its effect here - the events of the past are better remembered by those who have recently experienced them.

Gender equality lessons were remembered by $1 \%$ of all surveyed students (or $6 \%$ of those who learned about gender equality from secondary school teachers). This topic was most often discussed in other school lessons ( $11 \%$ of all respondents, or $60 \%$ of those who learned about gender equality in school), or teachers talked to former students about gender equality in extra-curricular activities $(9 \%$ of all respondents, or $40 \%$ of those who learned about gender equality in school) (Figure 3). 


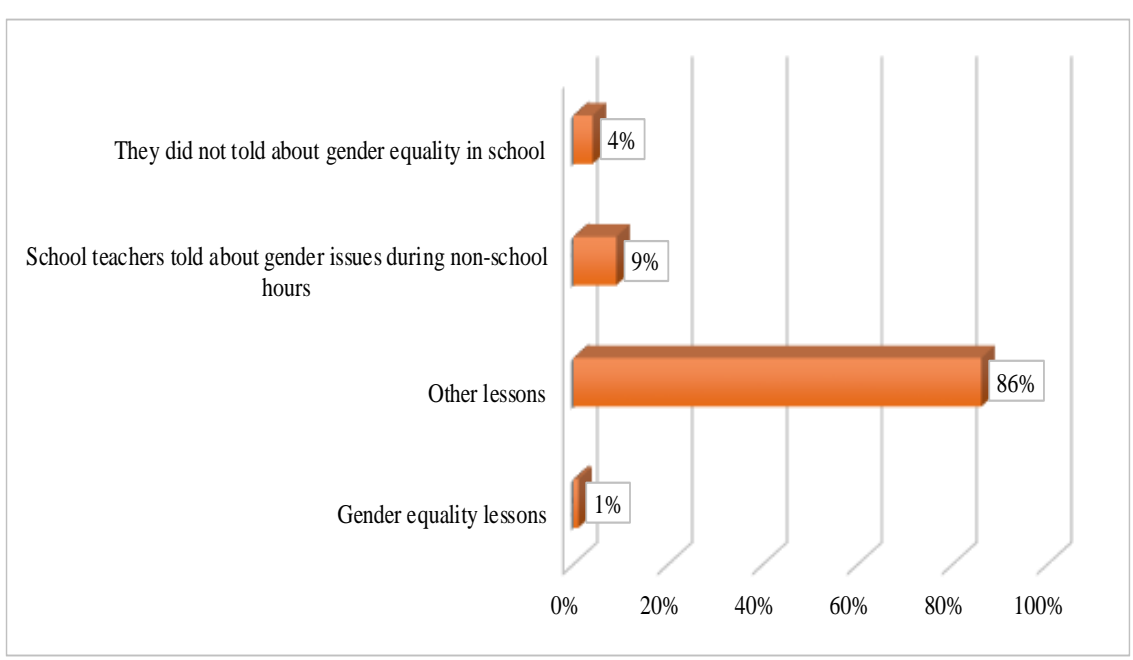

Figure 3: "In which lessons were the issues of gender equality discussed?", \%* Population: all respondents $(n=800)$.

*When answering the question "In which lessons were the issues of gender equality discussed?", respondents could select more than one answer, so the sum of all variants may exceed $100 \%$.

Responding to the question on during which lessons, apart from the gender equality lesson, students were told about gender issues, $86 \%$ responded "other lessons", supplementing their answers with the names of school subjects, such as law, legal science - 14\%; history, history of Ukraine - 13\%; man and society, man and the world, sociology $-10 \%$; health and safety $-7 \%$; biology, valeology - 6\%; Ukrainian literature, Russian literature - 5\%; ethics, aesthetics, culturology, family ethics $-5 \%$; psychology $-2 \%$; geography $1 \%$; English language $-1 \%$; economics $-1 \%$; philosophy $-1 \%$; other subjects $-3 \%$.

Let's consider the issue of gender education in higher education institutions. Gender issues are discussed much more often in higher education institutions than in secondary schools - about one in three students discussed gender equality issues at a university (Figure 4).

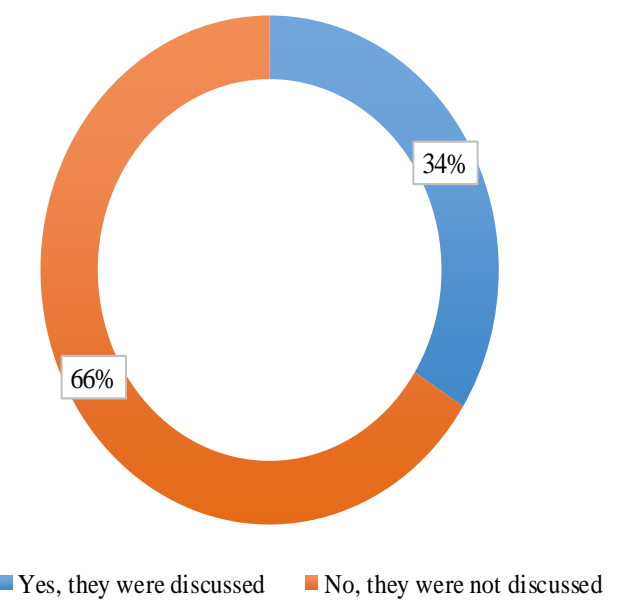

Figure 4: "Were gender equality issues discussed in your HEI?", \%. Population: all respondents $(n=800)$ 
Gender issues are much more often discussed with students in sociohumanities faculties. This finding is associated with the training programmes and curricula of Ukrainian universities. It can also be said that female students more often are involved in the discussion of gender issues in HEI than male students, but this difference is statistically insignificant and is due to the fact that females are more likely to study at socio-humanities faculties, that is, in subjects such as law, history, social sciences and languages. The comments of respondents in the "other" option column are almost identical - teachers told schoolchildren about gender equality during "klassny chas" (homeroom period), in an open lesson on September 1, or after the "last bell"; thus, these answers complemented the option "teachers talked about gender issues during non-school hours".

There is a dependence of the frequency of discussion of gender equality issues during the classes in HEI on the year of study of students (Figure 5). The higher the year of study, the more often students discussed these topics during classes. In general, this is not surprising as, the higher the year of study of students, the more courses they took, and the more likely it was that the issues under discussion were raised in some of them. However, these differences are quite small (statistically insignificant, at the level of $5 \%$ ).

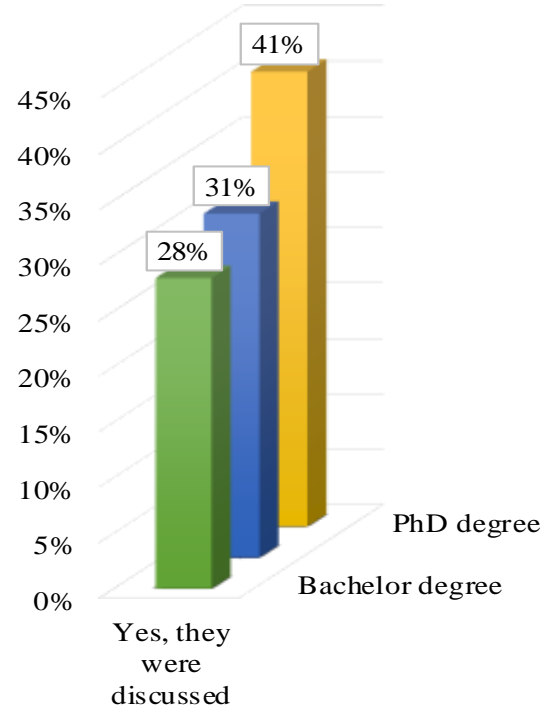

Figure 5: "Were gender equality issues discussed in your HEI?" Distribution of answers depending on the level of education of respondents, \%. Populations: students with the degrees of "bachelor" $(\mathrm{n}=224)$, "master" $(\mathrm{n}=248)$, and PhD $(\mathrm{n}=392)$

Let's see at what classes the problems of gender equality were discussed (Figure 6). In this study, we came across only one special course on gender issues, namely "Gender Psychology", offered at a psychology faculty of one HEI (3\% of all respondents and $10 \%$ of those students who discussed the issues of gender equality at HEIs). 


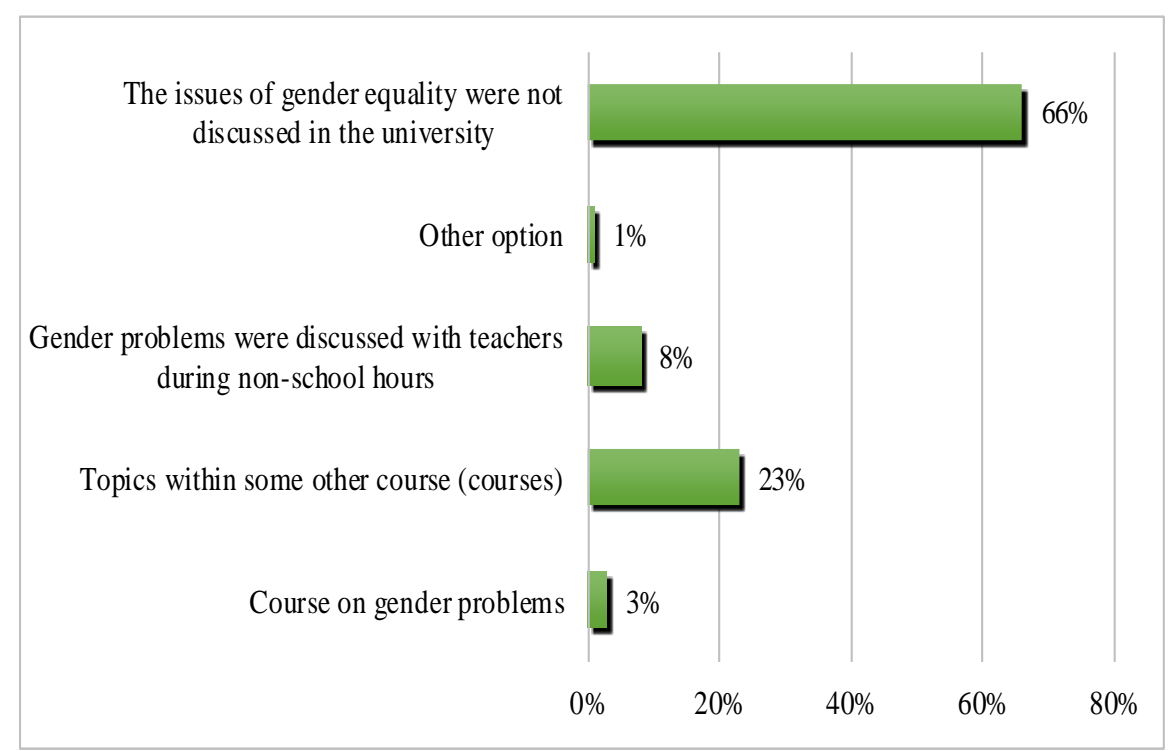

Figure 6: "At what classes were the problems of gender equality discussed?", \%; Population: all respondents $(n=800)$

When answering the question "At what classes were the problems of gender equality discussed?", respondents could select more than one answer option, so the sum of all options may exceed $100 \%$.

Most often, gender issues are discussed within some topics of other courses (Table 2). This was reported by $23 \%$ of all respondents $(73 \%$ of those who discussed gender equality in HEIs).

Table 2: Other university courses where gender issues were discussed, $\%$

\begin{tabular}{|l|l|}
\hline Course name & $\%$ \\
\hline Sociology, sociological disciplines & 41 \\
\hline Psychology, psychological disciplines & 9 \\
\hline Culturology & 6 \\
\hline Philosophy & 5 \\
\hline Theory of state and law, constitutional law & 5 \\
\hline Demography & 4 \\
\hline Political Science & 3 \\
\hline Ecology, theory of evolution & 2 \\
\hline Ethics & 2 \\
\hline Rhetoric & 1 \\
\hline History & 1 \\
\hline Other courses & 4 \\
\hline
\end{tabular}

Notes: Population: male and female students who discussed gender equality issues in higher education institutions $(n=274)$

Gender issues are discussed with teachers outside the classroom $(8 \%$ of all respondents and $23 \%$ of those who discussed gender equality in HEIs). The item "Other" option remains $1 \%$ and 3\%, respectively. Among the comments made by male and female students, the following were the most common: "a 
scientific conference on gender equality was held", "gender issues were the topic of the meeting of a scientific group", "this was the topic (related to the topic) of a term paper".

One of the important indicators of the effectiveness of gender education is the ability of students to explain the meaning of the term "gender" in such phrases as "gender policy", "gender equality", and "gender parity". In conclusion, it was deemed important to determine the level of involvement of respondents in gender issues. A direct, formalized question was posed to measure this aspect: "How clear is the meaning of the term 'gender' to you in phrases such as 'gender policy', 'gender equality'?". This question was supplemented by a request to explain in their own words what gender equality is (an open question in the questionnaire).

About understanding of the concept of "gender", $70 \%$ of the respondents answered they understood the concept. Almost a third of all respondents (32\%) expressed readiness to define the concept of "gender" and another $38 \%$ said they understood the concept, although it is was difficult for them to define it, and $30 \%$ of respondents admitted that the concept of "gender" was not familiar to them (Figure 7).

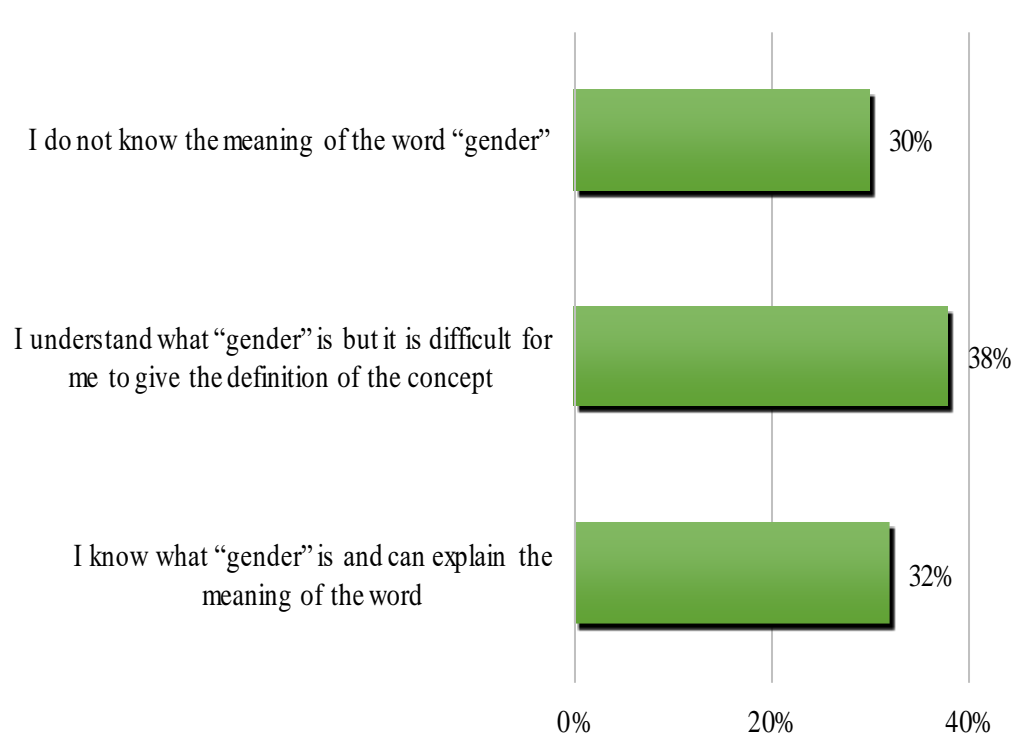

Figure 7: "How clear is the meaning of the term 'gender' to you in phrases such as 'gender policy', 'gender equality'?", \%. Population: all respondents $(n=800)$

How honest were the respondents answering the direct question about the understanding of the concept of "gender"? To determine this, the content of the responses to the open question, "Explain in your own words what gender equality is?" was analysed. This question was answered by $54 \%$ of the respondents, and if one excludes meaningless answers, the number of those who answered, is exactly $50 \%$. The answers of the respondents were classified. The results of this classification are presented in Table 3. 
Table 3: "Explain in your own words what gender equality is" \%

\begin{tabular}{|c|c|c|c|}
\hline Typ & Answe & Answer & $\%$ \\
\hline I & $\begin{array}{l}\text { A definition is given } \\
\text { when a respondent } \\
\text { understands who is } \\
\text { equal }\end{array}$ & $\begin{array}{l}\text { Gender equality. } \\
\text { Equality of men and } \\
\text { women. } \\
\text { Equality of men and } \\
\text { women in society. } \\
\text { Equality of men and } \\
\text { women in the modern } \\
\text { world. } \\
\text { Equality of men and } \\
\text { women in different } \\
\text { spheres of life. } \\
\text { Gender equality in life } \\
\text { situations. } \\
\text { Gender equality in } \\
\text { social issues. }\end{array}$ & 27 \\
\hline II & $\begin{array}{l}\text { A definition is given } \\
\text { when a respondent } \\
\text { understands who } \\
\text { and what is equal, } \\
\text { including detailed } \\
\text { answers, the } \\
\text { respondent's } \\
\text { reasoning }\end{array}$ & $\begin{array}{l}\text { Equality of rights for } \\
\text { men and women. } \\
\text { Equality of rights and } \\
\text { opportunities of men } \\
\text { and women. } \\
\text { Equality of social role, } \\
\text { rights, freedoms and } \\
\text { opportunities of men } \\
\text { and women. } \\
\text { Men and women } \\
\text { having equal rights to } \\
\text { education, work, } \\
\text { etc. } \\
\text { Equality of men and } \\
\text { women in their rights, } \\
\text { non-discrimination of } \\
\text { women. } \\
\text { Equal opportunities for } \\
\text { men and women in } \\
\text { achieving life goals, } \\
\text { professional growth. }\end{array}$ & 23 \\
\hline III & $\begin{array}{l}\text { Meaningless } \\
\text { definitions }\end{array}$ & $x$ & 3 \\
\hline IV & Borrowed answers & $\mathrm{X}$ & 1 \\
\hline $\mathrm{V}$ & No answer & $\mathrm{X}$ & 46 \\
\hline
\end{tabular}

The level of understanding of what "gender" is, did not depend on the gender of the respondents - 55\% of males and $46 \%$ of females had no idea of the meaning of this concept (the relation is weak, the differences are not significant at $5 \%$ ). It is interesting to note that according to the results of the formalized question, the responses of female and male respondents differed significantly. The level of misunderstanding by respondents of phrases with the word "gender" was $37 \%$ among males and $25 \%$ among females. 
Significant differences were expected in the answers of "physicists" and "lyricists". But the actual differences were small: $56 \%$ of "physicists" and $44 \%$ of "lyricists" knew nothing about gender and gender equality (the relation is still weak, but the differences in percentages are statistically significant at $5 \%$ ). Thus, as a result of the semantic analysis of free answers it may be concluded that there was no distinct difference in the understanding of gender categories by students of different types of faculties.

One can talk about small and quite predictable differences in the answers of respondents of different study years - first- and second-year students were slightly less informed about gender categories than upper-year students - the percentages of those who were not familiar with the concept of "gender" are $54 \%$ and $45-47 \%$, respectively. The involvement of students from different localities in gender issues was approximately equal.

\section{Discussion}

The situation is partially saved by teachers and professors of various humanities who draw the attention of schoolchildren and students in their classes to gender issues. Without these initiatives, discussion of gender issues in schools and HEIs would have been catastrophically small.

In our opinion, among the promising areas for further change, the following are the most important:

a. Approve the Strategy for the Implementation of Gender Equality in Education (Mardashova et al., 2021).

b. Work on the integration of a gender-sensitive approach in the system of preschool education, in particular, training for authors of preschool education programmes and provide them with counselling; provide advanced training for teachers of preschool institutions to increase their gender competence (Dorji, 2020).

c. Create a mechanism of anti-discrimination assessment of the entire educational process at all levels as currently this assessment is passed only by school textbooks, which are published at the expense of the budget (Keddie, 2020).

d. Review career guidance programmes, which often are based on gender stereotypes (Kellett \& Fitton, 2017).

e. Strengthen professional research on gender issues in the field of higher education and science, introduce gender optics in the teaching of professional courses in various subjects, especially the humanities (Dvoriak et al., 2020).

\section{Conclusion}

Based on the findings of the study, the following conclusions can be drawn. When asked about the existence and nature of gender discrimination in the Ukraine, almost half of all respondents believed that gender discrimination in Ukraine affects both genders although in different spheres of life. Unfortunately, a significant proportion of respondents $(28 \%)$ did not recognise the problem at all, as they believed that in most spheres of life men and women have equal rights and opportunities. Only one in five believed that men have more rights and opportunities. 
At school, the problems of gender equality are not discussed enough; more than $80 \%$ of all respondents did not learn anything on this topic at school. As for HEIs, special subjects on gender equality are not yet offered to most students. At best, students discuss these issues as separate topics within the general courses of sociology, psychology, culturology, and other subjects. Students of faculties of sociology, psychology, philosophy, and other human sciences had relatively greater opportunities to become informed about gender issues, as these are included in various special subjects that they studied.

Despite these findings, the level of student involvement in gender issues cannot be considered low, as it is clear that educational institutions are not the only source of information for young people. The level of interest of students in discussing the topic of gender equality also adds some optimism.

Detail of the design of training programmes in accordance with the standards of the Ministry of Education and Science of Ukraine (MESU) posed a limitation to conducting this study. At the social and humanities faculties, for example, there are more subjects related to gender, thus, naturally, these students are more familiar with this issue. In future, it will be necessary to adjust the standards of the Ministry of Education and Science regarding the issue of gender education for all students.

\section{References}

Addabbo, T., Di Tommaso, M. L. \& Maccagnan, A. (2016). Education capability: A focus on gender and science. Social Indicators Research, 128(2), 793-812. https:// doi.org/10.1007/s11205-015-1057-8

Amado, N. \& Diniz, A.M. (2017). Strength of religious faith in the Portuguese Catholic elderly: Effects of aging, gender, education, and religious participation. Archive for the Psychology of Religion, 39(1), 82-98.

Assari, S. (2017). Social determinants of depression: The intersections of race, gender, and socioeconomic status. Brain Sciences, 7(12), 156. https://doi.org/10.3390/brainsci7120156

Bailey, L.E. \& Graves, K. (2016). Gender and education. Review of Research in Education, 40(1), 682-722. https://doi.org/10.3102/0091732X16680193

Baizan, P., Arpino, B. \& Delclós, C.E. (2016). The effect of gender policies on fertility: The moderating role of education and normative context. European Journal of Population, 32(1), 1-30. https:/ / doi.org/10.1007/s10680-015-9356-y

Baker, J.O. \& Whitehead, A.L. (2016). Gendering (non) religion: Politics, education, and gender gaps in secularity in the United States. Social Forces, 94(4), 1623-1645. https://doi.org/10.1093/sf/sov119

Bertocchi, G. \& Bozzano, M. (2016). Women, medieval commerce, and the education gender gap. Journal of Comparative Economics, 44(3), 496-521. https://doi.org/10.1016/j.jce.2015.09.002

Burke, P.J. (2017). Difference in higher education pedagogies: Gender, emotion and shame. Gender and Education, 29(4), 430-444. https://doi.org/10.1080/09540253.2017.1308471

Cama, M.G., Jorge, M.L. \& Peña, F.J.A. (2016). Gender differences between faculty members in higher education: A literature review of selected higher education journals. Educational Research Review, 18, 58-69. https://doi.org/10.1016/j.edurev.2016.03.001 
Caner, A., Guven, C., Okten, C. \& Sakalli, S.O. (2016). Gender roles and the education gender gap in Turkey. Social Indicators Research, 129(3), 1231-1254. https://doi.org/10.1007/s11205-015-1163-7

Colgan, J. (2017). Gender bias in international relations graduate education? New evidence from syllabi. PS: Political Science \& Politics, 50(2), 456-460. https://doi.org/10.1017/S1049096516002997

Cotton, D.R., Joyner, M., George, R. \& Cotton, P.A. (2016). Understanding the gender and ethnicity attainment gap in UK higher education. Innovations in Education and Teaching International, 53(5), 475-486. https://doi.org/10.1080/14703297.2015.1013145

Dobson, A.S. \& Ringrose, J. (2016). Sex education: Pedagogies of sex, gender and shame in the schoolyards of Tagged and Exposed. Sex Education, 16(1), 8-21. https://doi.org/10.1080/14681811.2015.1050486

Dorji, T. (2020). Gender Responsive Pedagogy Awareness and Practices: A Case Study of a Higher Secondary School under Thimphu Thromde, Bhutan. International Journal of Linguistics and Translation Studies, 1(2), 100-111. https://doi.org/10.36892/ijlts.v1i2.21

Dvoriak, S., Karagodina, O. \& Semigina, T. (2020). Gender competences of social work students: Do we need a transformative approach? Social Work and Education, 7(3), 279-288.

Eddy, S.L. \& Brownell, S.E. (2016). Beneath the numbers: A review of gender disparities in undergraduate education across science, technology, engineering, and math disciplines. Physical Review Physics Education Research, 12(2), 20106. https:// doi.org/10.1103/PhysRevPhysEducRes.12.020106

Francis, U.C. \& Chiyem, N.L. (2017). Gender, education and marital status as determinants of leadership styles among pastoral leaders. International Journal of English Literature and Social Sciences, 2(5), 239213. https://doi.org/10.24001/ijels.2.5.3

Gibson, P.A., Baker, E.H. \& Milner, A.N. (2016). The role of sex, gender, and education on depressive symptoms among young adults in the United States. Journal of Affective Disorders, 189, 306-313. https:/ / doi.org/10.1016/j.jad.2015.08.067

Hauw, Y. De., Grow, A. \& Van Bavel, J. (2017). The reversed gender gap in education and assortative mating in Europe. European Journal of Population, 33(4), 445-474. https:// doi.org/10.1007/s10680-016-9407-z

Karhina, K., Ng., N., Ghazinour, M. \& Eriksson, M. (2016). Gender differences in the association between cognitive social capital, self-rated health, and depressive symptoms: A comparative analysis of Sweden and Ukraine. International Journal of Mental Health Systems, 10(1), 1-14. https:// doi.org/10.1186/s13033-016-0068-4

Keddie, A. (2020). Engaging boys and young men in gender transformation: The possibilities and limits of a pedagogy of empathy. Norma, 15(2), 97-110. https://doi.org/10.1080/18902138.2019.1706883

Kellett, P., \& Fitton, C. (2017). Supporting trans-visibility and gender diversity in nursing practice and education: Embracing cultural safety. Nursing Inquiry, 24(1), 12146. https:// doi.org/10.1111/nin.12146

Kim, M., \& Park, J. M. (2017). Factors affecting cognitive function according to gender in community-dwelling elderly individuals. Epidemiology and Health, 39. https://doi.org/10.4178/epih.e2017054

Klein, U. (2016). Gender equality and diversity politics in higher education: Conflicts, challenges and requirements for collaboration. Women's Studies International Forum, 54, 147-156. https:// doi.org/10.1016/j.wsif.2015.06.017 
Kleven, H. \& Landais, C. (2017). Gender inequality and economic development: Fertility, education and norms. Economica, 84(334), 180-209. https://doi.org/10.1111/ecca.12230

Leyva, L.A. (2017). Unpacking the male superiority myth and masculinization of mathematics at the intersections: A review of research on gender in mathematics education. Journal for Research in Mathematics Education, 48(4), 397-433. https:// doi.org/10.5951/jresematheduc.48.4.0397

Magnuson, K.A., Kelchen, R., Duncan, G.J., Schindler, H.S., Shager, H. \& Yoshikawa, H. (2016). Do the effects of early childhood education programs differ by gender? A meta-analysis. Early Childhood Research Quarterly, 36, 521-536. https://doi.org/10.1016/j.ecresq.2015.12.021

Mardashova, R., Garnysheva, T., Sharafetdinova, Z., Konovalova, E., Khakimova, G. \& Khakimova, N. (2021). Issues of gender pedagogy: Teaching boys the masculinity (preschool childhood stage). In E3S Web of Conferences, 258. EDP Sciences. https://doi.org/10.1051/e3sconf/202125810022

Molina, T. (2016). Reporting heterogeneity and health disparities across gender and education levels: Evidence from four countries. Demography, 53(2), 295-323. https:// doi.org/10.1007/s13524-016-0456-z

Muralidharan, K. \& Sheth, K. (2016). Bridging education gender gaps in developing countries: The role of female teachers. Journal of Human Resources, 51(2), 269-297. https:// doi.org/10.3368/jhr.51.2.0813-5901R1

Núñez-Peña, M.I., Suárez-Pellicioni, M. \& Bono, R. (2016). Gender differences in test anxiety and their impact on higher education students' academic achievement. Procedia-Social and Behavioral Sciences, 228, 154-160. https:// doi.org/10.1016/j.sbspro.2016.07.023

Orakci, S., Aktan, O., Toraman, Ç. \& Çevik, H. (2016). The Influence of Gender and Special Education Training on Attitudes Towards Inclusion. International Journal of Instruction, 9(2), 107-122.

Pampel, F.C., Bricard, D., Khlat, M. \& Legleye, S. (2017). Life course changes in smoking by gender and education: A cohort comparison across France and the United States. Population Research and Policy Review, 36(3), 309-330. https://doi.org/10.1007/s11113-016-9424-y

Reimão, M.E. \& Taş, E.O. (2017). Gender Education Gaps among Indigenous and Non-Indigenous Groups in Bolivia. Development and Change, 48(2), 228-262. https://doi.org/10.1111/dech.12292

Salavera, C., Usan, P. \& Jarie, L. (2017). Emotional intelligence and social skills on selfefficacy in secondary education students: Are there gender differences? Journal of Adolescence, 60, 39-46. https://doi.org/10.1016/j.adolescence.2017.07.009

Setti, Z. (2017). Entrepreneurial intentions among youth in MENA countries: Effects of gender, education, occupation and income. International Journal of Entrepreneurship and Small Business, 30(3), 308-324.

Struffolino, E., Studer, M. \& Fasang, A.E. (2016 ). Gender, education, and family life courses in East and West Germany: Insights from new sequence analysis techniques. Advances in Life Course Research, 29, 66-79. https://doi.org/10.1016/j.alcr.2015.12.001

Subbaye, R. \& Vithal, R. (2017). Gender, teaching and academic promotions in higher education. Gender and Education, 29(7), 926-951. https://doi.org/10.1080/09540253.2016.1184237

Tansel, A. \& Güngör, N.D. (2016). Gender effects of education on economic development in Turkey. In Women, Work and Welfare in the Middle East and North Africa: 
The Role of Socio-demographics. Entrepreneurship and Public Policies, 57-86. https://doi.org/10.1142/9781783267347_0003

Tetzner, J. \& Schuth, M. (2016). Anxiety in late adulthood: Associations with gender, education, and physical and cognitive functioning. Psychology and Aging, 31(5), 532-544. https://doi.org/10.1037/pag0000108

Van der Vleuten, M., Jaspers, E., Maas, I. \& van der Lippe, T. (2016). Boys' and girls' educational choices in secondary education. The role of gender ideology. Educational Studies, 42(2), 181-200. https://doi.org/10.1080/03055698.2016.1160821

Warin, J. \& Adriany, V. (2017). Gender flexible pedagogy in early childhood education. Journal of Gender Studies, 26(4), 375-386. https://doi.org/10.1111/cdev.12642

$\mathrm{Xu}, \mathrm{Y} . J$. (2016). Aspirations and application for graduate education: Gender differences in low-participation STEM disciplines. Research in Higher Education, 57(8), 913942. https://doi.org/10.1007/s11162-016-9411-5

\section{Appendix.}

\section{Appendix A. Distribution of survey respondents by corresponding characteristics}

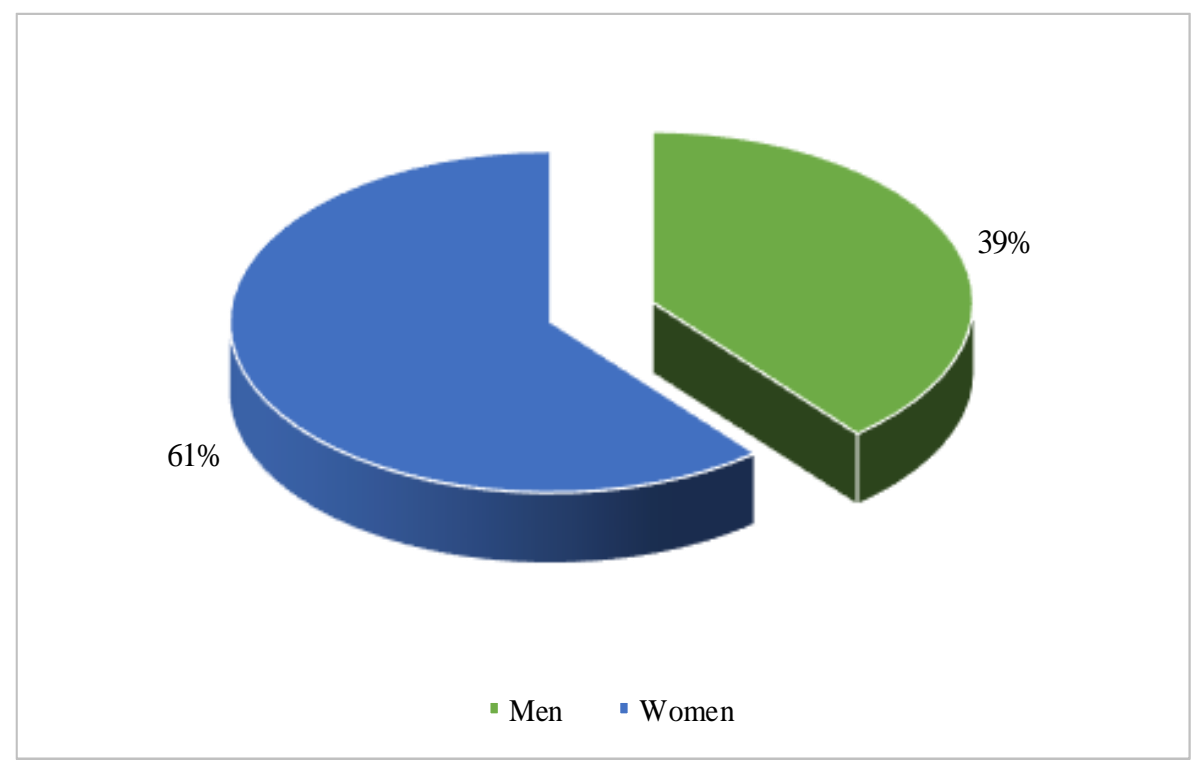

Figure A1: Distribution of respondents by gender, $\%$ 


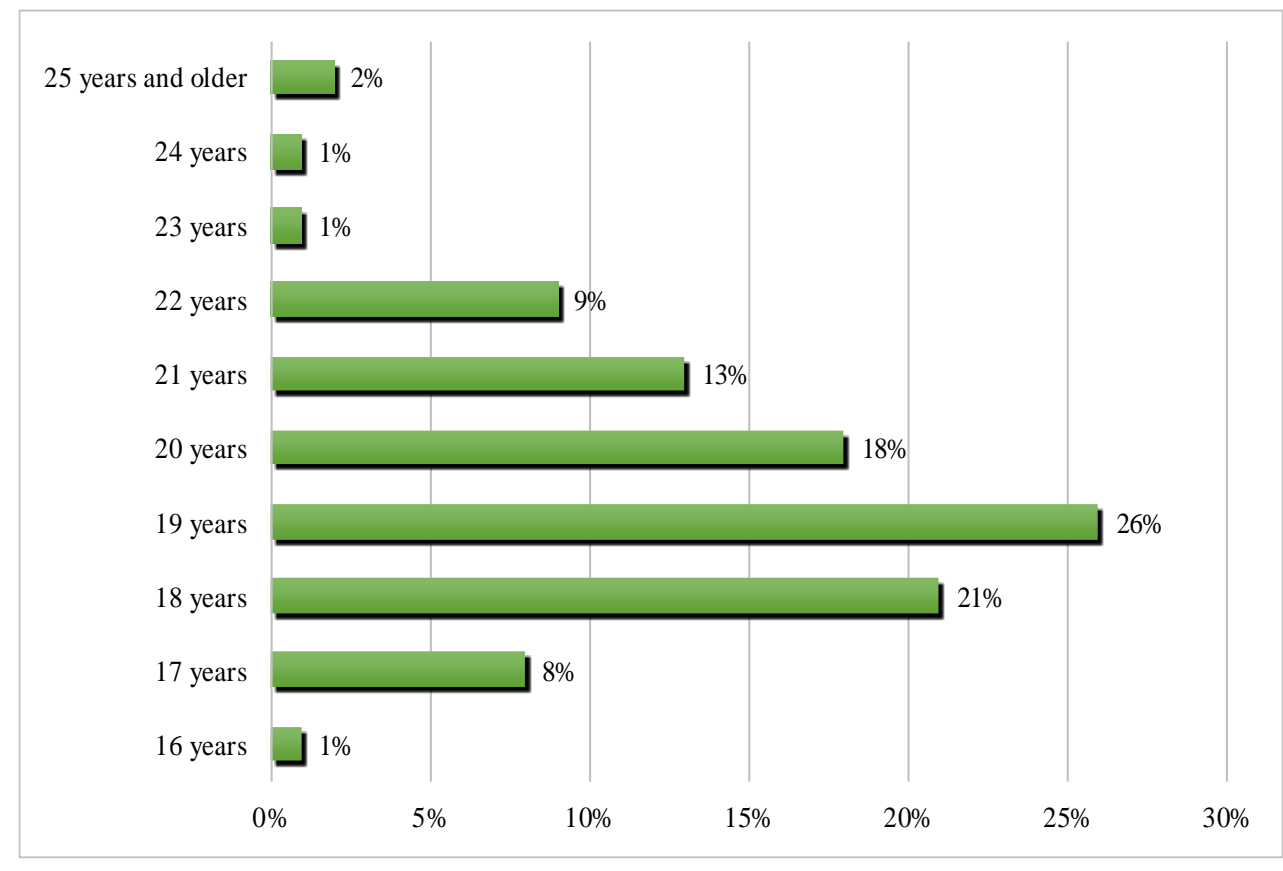

Figure A2: Distribution of respondents by age, $\%$

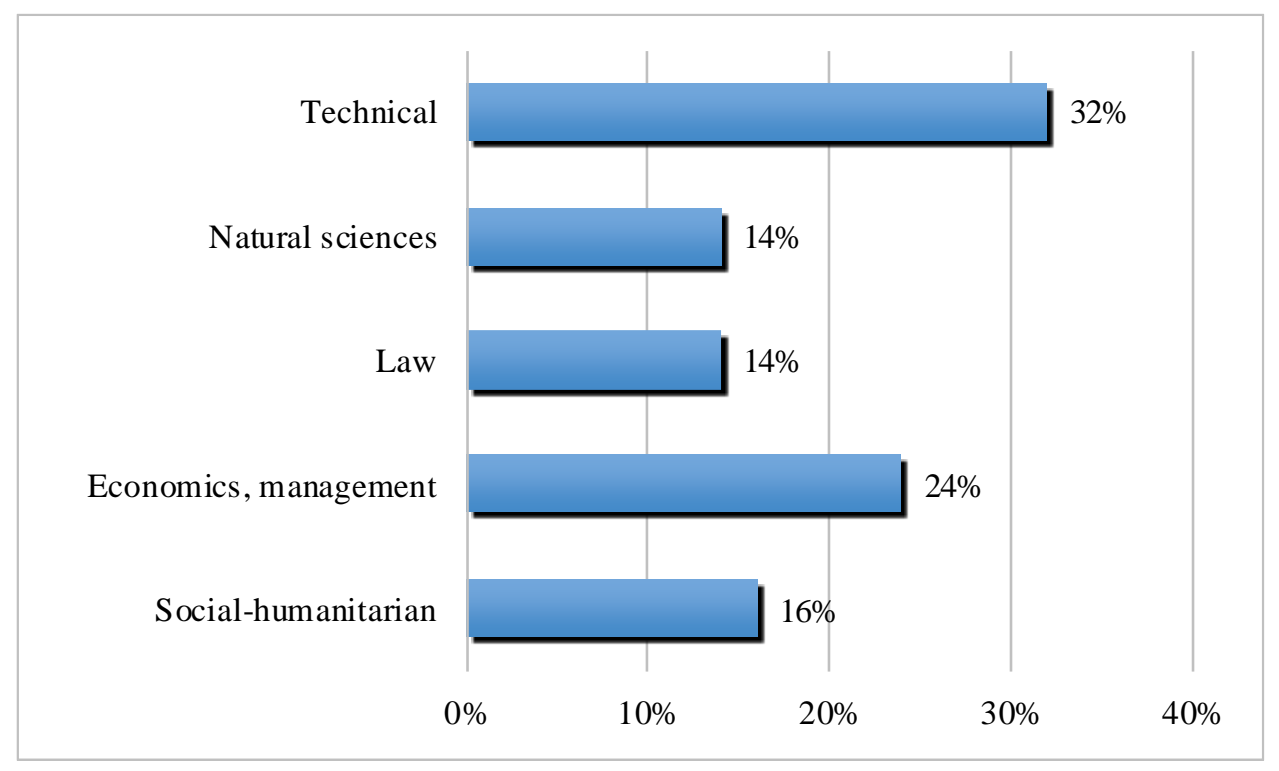

Figure A3: Distribution of respondents by faculty, \% 


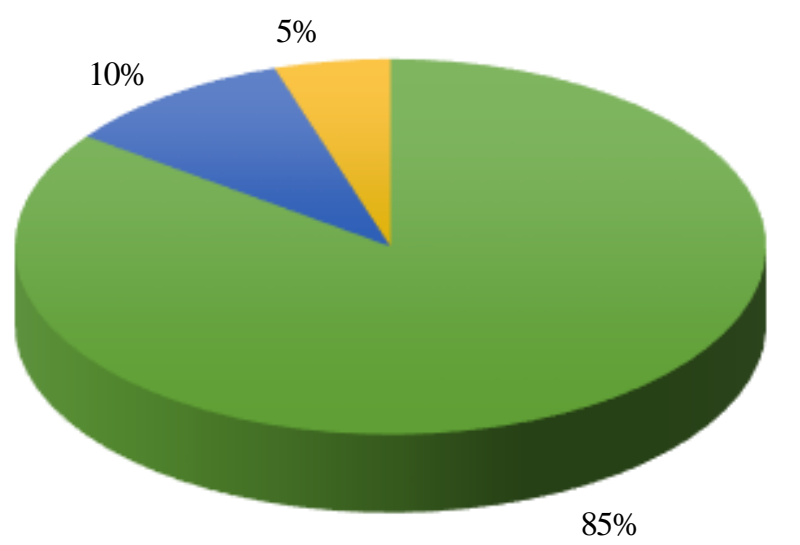

Bachelor degree $\quad$ Master degree $\quad \mathrm{PhD}$ degree

Figure A4: Distribution of respondents by education level, $\%$ 